\author{
O.F. SOVTUS, R.V.SABADOSH
}

\title{
USE OF ENDOVASCULAR AND COMBINED INTERVENTIONS IN OBLITERATING OCCLUSIVE-STENOTIC ARTERIAL DISEASES OF THE LOWER LIMBS
}

\author{
Ivano-Frankivsk National Medical University, Ivano-Frankivsk, \\ Ukraine
}

\begin{abstract}
Цель. Улучшить результаты лечения пациентов с окклюзионно-стенотическими поражениями артерий нижних конечностей, при которых открытые операции невозможны или сопряжены с высоким риском, путем применения эндоваскулярных вмешательств.

Материал и методы. Пролечены 53 пациента, которым эндоваскулярно реваскуляризированы разные сегменты артерий нижних конечностей (I группа - аорто-подвздошный с/без бедренно-подколенного; IIA - бедренно-подколенный; ІІБ - бедренно-подколенный и инфрапоплитеальный; III - инфрапоплитеальный) с/без дополнительных открытых операций на иных сегментах. В течение года оценивали технический успех процедур; первичную и вторичную проходимость зон вмешательства, частоту сохранения и степень ишемии конечностей.

Результаты. Технический успех достигнут у 94,3\% пациентов, однолетняя вторичная проходимость у $92,5 \%$, сохранение конечностей - у 96,2\%. В І группе, где $60 \%$ пациентам проведены гибридные операции (эндоваскулярный этап - на аорто-подвздошном сегменте), позитивный технический результат получен у всех пациентов; в течение 1 года тромбозов стентов, некротических процессов, ишемии выше IIA степени (Fontaine) не наблюдалось. Идентичные результаты получены во IIA группе. B III группе, основу которой составили больные с тотальной окклюзией магистральных артерий голени и стопы или тотальным циркулярным кальцинозом их постокклюзионных сегментов, технический успех составил 84,6\%, однолетняя первичная проходимость $-76,9 \%$, а сохранение конечности $-100 \%$. Во ІІБ группе эти показатели составили $91,7,75,0$ и $83,3 \%$, соответственно.

Заключение. Взвешенное применение эндоваскулярных вмешательств при стенозах и окклюзиях артерий нижних конечностей позволяет достичь технического успеха, первичной и вторичной проходимости зоны интереса и однолетнего сохранения конечности у 88,7-96,2\% пациентов. Эндоваскулярное лечение может быть рекомендован как метод выбора при полной окклюзии магистральных артерий голени и стопы, тотальном циркулярном кальцинозе их постокклюзионных сегментов и для реваскуляризации аорто-подвздошного сегмента при его сочетанных поражениях с бедренно-подколенным сегментом при гибридных операциях.
\end{abstract}

Ключевые слова: периферические заболевания артерий, критическая ишемия конечностей, баллонная ангиопластика нижних конечностей, стентирование, гибридные процедуры

Objective. To improve the results of treatment in patients with lower limb artery occlusive-stenotic diseases, where open operations are impossible or involve a high risk, by using endovascular interventions.

Methods. 53 patients have been treated, they underwent endovascular revascularization of lower limb artery different segments (I group - aortoiliac with or without femoropopliteal; IIA - femoropopliteal; IIB femoropopliteal and infrapopliteal; III - infrapopliteal) with/without of the additional open operations on other segments. During the year a technical success of the procedures, the primary and secondary patency of intervention zones, the frequency of conservation and the degree of limb ischemia were assessed.

Results. The technical success was achieved in $94.3 \%$ of patients, 1-year secondary patency was achieved in $92.5 \%$, the preservation of the lower limbs was achieved in $96.2 \%$. In group I, where $60 \%$ of patients underwent hybrid operations (endovascular stage - on aortoiliac segment), a positive technical result was obtained in all the patients; stent thrombosis, necrotic processes, ischemia above grade IIA (Fontaine) were not observed during one year. Identical results were obtained in the IIA group. In the III group, which was based on patients with total occlusion of the lower leg and foot main arteries or total circular calcification of their post-occlusal segments, the technical success was $84.6 \%$, the one-year primary patency was $76.9 \%$, and limb salvage was $100 \%$. In Group IIB these indicators were $91.7,75.0$ and $83.3 \%$, respectively.

Conclusions. The careful application of endovascular interventions in stenosis and occlusions of the lower limbs arteries allows achieving technical success, primary and secondary patency of the revascularization zone and one-year limb salvage in 88.7-96.2\% of patients. Endovascular treatment can be recommended as the method of choice in complete occlusion of the lower leg and foot main arteries, total circular calcification of their post-occlusal segments and for revascularization of aortoiliac segment in case of its combined lesions with the femoropopliteal segment at hybrid operations. procedures

Keywords: peripheral arterial disease, critical limb ischemia, lower limb balloon angioplasty, stenting, hybrid 


\section{Научная новизна статьи}

Получены новые данные, подтверждающие, что эндоваскулярное лечение таких поражений инфрапоплитеального артериального сегмента, как тотальная окклюзия всех магистральных артерий голени и стопы или тотальный циркулярный кальциноз их постокклюзионных сегментов, может быть признано тактикой выбора. Продемонстрировано, что взвешенное применение эндоваскулярных операций при окклюзионных поражениях разных сегментов артерий нижних конечностей позволяет достичь технического успеха у $94,3 \%$ пациентов, вторичной проходимости в течение года - у 92,5 \% и сохранения нижних конечностей - у $96,2 \%$.

\section{What this paper adds}

New data have been obtained confirming that endovascular treatment of such lesions of the infrapopliteal arterial segment, such as total occlusion of all major arteries of the shin and foot, or total circular calcification of their post-occlusal segments, can be recognized as a tactic of choice. It has been shown that weighted application of endovascular operations with occlusive lesions of different segments of the arteries of the lower limbs allows achieving technical success in $94.3 \%$ of patients, secondary permeability during the year - in $92.5 \%$ and preservation of the lower limbs - in $96.2 \%$.

\section{Introduction}

Ensuring the qualitative and timely treatment of patients with critical ischemia of the lower limbs is one of the most important challenges of modern vascular surgery. Shunt reconstructive interventions in this pathology remain the gold standard of the lower limb revascularization. Significant progress in the development of endovascular methods of restoration of the main blood flow caused their more frequent use, especially in older patients with high surgical risk. In addition, it became possible to carry out combined two-stage or hybrid interventions in multi-storey atherosclerotic lesions [1].

In the transatlantic consensus document TASC-II (2007), the choice of intervention (endovascular or open surgical) was based on the TASC classification of occlusal-stenotic lesions of lower limb arteries [2]. Endovascular revascularization is recognized as a method of choice in patients with type A lesion, the preferred method in patients with type B and a possible (but not optimal) method for type C lesions. For Type D lesions, based on evidence available at the time, only surgical revascularization was recommended.

The rapid development of endovascular technologies has led to the endovascular strategy recommended in 2011 by the European Society of Cardiology as a method of choice already in the case of lesions of A-C types and as a possible treatment method - for lesions of type D [3]. But in 2017, the recommendations of the European Society of Cardiology together with the European Society for Vascular Surgery were more restrained, and the primary endovascular strategy in the absence of severe concomitant diseases was recommended only in patients with short occlusive-stenotic lesions $(<5 \mathrm{~cm}$ for aortoiliac lesions and $<25 \mathrm{~cm}$ for femoropopliteal ones) [4], corresponding mainly to types A and B for the aortoiliac segment and A-C for femoropopliteal segment. It was in this document that the place of hybrid (combined) interventions was first determined. In patients with combined pathology of the aortoiliac and femoropopliteal segment, the use of such procedures (endovascular revascularization of the upper floor and surgical reconstruction of the lower one) permits to avoid complex aortofemoral reconstructions, reducing the risk for the patient.

But despite all mentioned above, a number of problems remain unsolved. First, all recommendations on the use of endovascular revascularization methods have a level of evidence not exceeding $\mathrm{C}$ and therefore the issue of selecting patients for endovascular interventions remains unresolved. Secondly, there are many questions on the management of patients with various infrapopliteal lesions of the arteries. Thirdly, indications on the use of endovascular and open surgical interventions in hybrid procedures are not clearly defined. Solving these issues can significantly optimize the therapeutic strategy in patients with peripheral arterial diseases, improving, ultimately, the results of their treatment.

Objective. To improve the results of treatment in patients with lower limb artery occlusive-stenotic diseases, where open operations are impossible or involve a high risk, by using endovascular interventions.

\section{Methods}

During 2013-2017 in Ivano-Frankivsk Central City Clinical Hospital endovascular interventions were performed in 53 patients with chronic obliterating diseases of the lower limbs arteries. The age of patients ranged from 46 to 87 years. The average age was $65.4 \pm 10.4$ years $(\mathrm{M} \pm \sigma)$. There were 41 men $(77.4 \%)$, women $-12(22.6 \%)$. There were 22 diabetic patients (41.5\%).

In the initial physical examination of patients, the following parameters were assessed: severity of chronic lower limb ischemia (according to Fontaine 
classification, 1954), recommended by the latest consensus documents [5]; the type of purulent necrotic lesion of the feet and/or shins, as well as the W and I criteria of the WifI classification (2014) [6]. After that, they were subject to standard general clinical studies, as well as lipidogram, determination of the level of glycosylated hemoglobin, echocardioscopy, ultrasonic triplex scanning of arteries of the lower limbs with calculation of the ankle-brachial index and criterion I of the above classification WifI, with the definition of the risk of amputation and the need for revascularization; extra-and intracranial, and renal arteries (LOGIQ e (GE Healthcare, UK) and TOSHIBA ffa-580a/ f7 (TOSHIBA, Japan), lower limb CT-aortoarteriography (Aquilion PRIME, Toshiba, Japan); radiopaque arteriography of the lower limbs (Infinix CC, Toshiba, Japan), if necessary - radiography of the foot.

Based on these studies, the affected arterial segments and types of lesions of each segment were determined in all patients: aortoiliac and femoropopliteal - by the mentioned above TASC classification (2007), and infrapopliteal by its complement for the infraropliteal segment [7]. Later, the segments that are subject to reconstruction and the method of reconstruction for each of them were identified. As evidence for the use of endovascular procedures, the above-mentioned recommendations of the European Society of Cardiology together with the European Society for Vascular Surgery of 2017 were applied. Depending on which arterial segment the endovascular revascularization method was planned, all patients were divided into four groups: group endovascular intervention exclusively on the aortoiliac segment or on the aortoiliac and femoropopliteal segments; II A group - exclusively on the femoropopliteal; II B group - on the femoropopliteal and infrapopliteal; III group - exclusively on the infraplanar arterial segment. In some patients, endovascular interventions on one or another arterial segment were supplemented by open operations on another segment, that is, one-stage hybrid or two-stage combined interventions were performed.

Clinical characteristics of patients of different groups are given in Table 1.

In all 15 patients of group I (93.3\%), together with the aortoiliac, the femoropopliteal segment was affected (Table 2). As the result in 9 patients $(60.0 \%)$ open bypass surgery was carried out on the femoropopliteal segment: in one case $(6.7 \%)$ simultaneously with endovascular intervention and in 8 cases $(53.3 \%)$ - as the second stage (all 9 patients with lesion of the femoropopliteal segment of type D). Another 3 patients $(20.0 \%)$ with the lesion of the femoral-popliteal segment of type A ( 2 cases) and B (1 case) underwent stenting of the femoral artery: in one patient $(6.7 \%)$ - simultaneously with aortoiliac segment intervention, and in the rest $(13.3 \%)$ - as the second stage.

When performing endovascular intervention in Group I patients, in 12 cases $(80.0 \%)$ the femoral access was used (in 5 patients - from the side of lesion, in 7 - with contralateral) and in 3 cases $(20.0 \%)$ - radial one. A special feature of the transradial strategy of revascularization was the bilateral puncture of the radial arteries with the setting of short radial introducers $6 \mathrm{~F}$. For visualization through the right radial access to the abdominal aorta bifurcation zone, an angiographic catheter $5 \mathrm{~F}$ was used, which was attached to the contrast injector (Fig. A). Through the left radial access, the main stage of the intervention was carried out. The conductor $0.035 " 0.89 \mathrm{~mm} 300 \mathrm{~cm}$ was introduced to the affected vessel (Fig. 1B), after which the balloon plastic was performed in the areas of narrowing of the iliac segment under the pressure of $12 \mathrm{~atm}$ and a stent was implanted with subsequent post-dilation with the same balloon (Fig. C, D).

Among 15 patients of Group I, in $12(80.0 \%)$, the peripheral self-expanding stents were implanted, and in the remaining $3(20.0 \%)$ - stents on cylinders.

Types of lesions of the femoropopliteal and infrapopliteal segments and characteristics of endovascular interventions performed in patients with IIA and IIB groups are presented in Table 3.

When performing interventions in patients assigned to the IIB group, operations in distal femoral artery occlusion in combination with popliteal artery occlusion, proximal segments of the tibioperoneal trunk and anterior tibial artery were technically more complicated. In such patients, coronary techniques and coronary instruments were used for revascularization. Antegrade passage of occlusion was performed with a microcatheter using 0.014 " coronary conductors. After passage of the occluded site, through the microcatheter, angiographic control of the distal segments of the open vessel was made. The coronary conductor was changed to a conductor of $0.014 " 300.0 \mathrm{~cm}$, on which balloon angioplasty of the femoral and/ or popliteal artery was carried out, followed by stenting of this segment and post-dilation. Balloon plastic of the tibial arteries was performed in two stages. First, it was retrograde (from the foot in the proximal direction) throughout the occluded site with a low-profile coronary $\mathrm{Rx}$ balloon catheter, size 1,5-2.0 mm, pressure 8 atmospheres and short exposure (1-2 seconds). Secondary angioplasty was performed by OTW balloon catheter, length 120-150 $\mathrm{mm}$ and working diameter $2.0-3.0 \mathrm{~mm}$, pressure 8 atmospheres and exposure 2 minutes.

As mentioned above, in the group of patients, 
(C) O.F. Sovtus et al. Endovascular operations on peripheral arteries

Basic and clinical characteristics of patients

\begin{tabular}{|c|c|c|c|c|c|c|c|c|c|}
\hline \multicolumn{5}{|c|}{ Characteristics of patients } & $\begin{array}{c}\text { All patients } \\
(\mathrm{n}=53)\end{array}$ & $\begin{array}{l}\text { I Group } \\
(\mathrm{n}=15)\end{array}$ & $\begin{array}{c}\text { IIA Group } \\
(\mathrm{n}=13)\end{array}$ & $\begin{array}{c}\text { IIB Group } \\
(n=12)\end{array}$ & $\begin{array}{c}\text { III Group } \\
(\mathrm{n}=13)\end{array}$ \\
\hline \multicolumn{5}{|c|}{ Average age, years () } & $65.4(10.4)$ & $65.5(10.8)$ & $64.8(13.4)$ & $67.5(10.6)$ & $64.1(7.0)$ \\
\hline \multirow[t]{2}{*}{ Sex } & \multirow{2}{*}{\multicolumn{2}{|c|}{ number $(\%)$ : }} & male & & $41(77.4)$ & $13(86.7)$ & $11(84.6)$ & $6(50.0)$ & $11(84.6)$ \\
\hline & & & female & & $12(22.6)$ & $2(13.3)$ & $2(15.4)$ & $6(50.0)$ & $2(15.4)$ \\
\hline \multirow{7}{*}{ 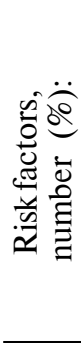 } & diabetes & mellitus & & & $22(41.5)$ & $6(40.0)$ & $5(38.5)$ & $3(25.0)$ & $8(61.5)$ \\
\hline & smoking & & & & $44(83.0)$ & $13(86.7)$ & $11(84.6)$ & $10(83.3)$ & $10(76.9)$ \\
\hline & arterial $\mathrm{h}$ & ypertension & & & $43(81.1)$ & $13(86.7)$ & $11(84.6)$ & $11(91.7)$ & $8(61.5)$ \\
\hline & cardiac $\mathrm{i}$ & chemia & & & $37(69.8)$ & $11(73.3)$ & $8(61.5)$ & $9(75.0)$ & $9(69.2)$ \\
\hline & $\begin{array}{l}\text { cerebral } \\
\text { anamnes }\end{array}$ & irculatory & ders in the & & $6(11.3)$ & $2(13.3)$ & $2(15.4)$ & $1(8.3)$ & $1(7.7)$ \\
\hline & chronic & enal failure & & & $2(3.8)$ & - & $1(7.7)$ & $1(8.3)$ & - \\
\hline & hyperlip & demia & & & 27 & 8 & 6 & 6 & 7 \\
\hline \multirow{3}{*}{\multicolumn{3}{|c|}{$\begin{array}{l}\text { The degree of ischemia } \\
\text { Fontaine, number }(\%) \text { : }\end{array}$}} & - IIB & & $5(9.4)$ & $3(20.0)$ & $2(15.4)$ & $\overline{-}$ & $\overline{-}$ \\
\hline & & & - III & & $14(26.4)$ & $3(20.0)$ & $5(38.5)$ & $1(8.3)$ & $5(8.9)$ \\
\hline & & & - IV & & $34(64.2)$ & $9(60.0)$ & $6(46.1)$ & $11(81.7)$ & $8(78.6)$ \\
\hline \multirow{18}{*}{ 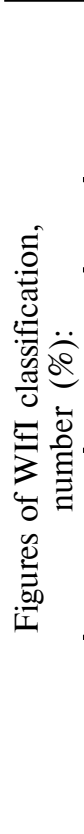 } & \multirow{4}{*}{\multicolumn{2}{|c|}{$\ddot{\vec{z}}$}} & & 0 & $19(35.8)$ & $6(40.0)$ & $7(53.8)$ & $1(8.3)$ & $5(38.5)$ \\
\hline & & & & 1 & $12(22.6)$ & $4(26.7)$ & $4(30.8)$ & $2(16.7)$ & $2(15.4)$ \\
\hline & & & & 2 & $18(34.0)$ & $5(33.3)$ & $2(15.4)$ & $7(58.3)$ & $4(30.8)$ \\
\hline & & & & 3 & $4(7.5)$ & & & $2(16.7)$ & $2(15.4)$ \\
\hline & \multirow{2}{*}{\multicolumn{2}{|c|}{ 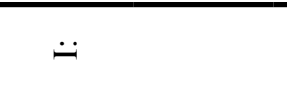 }} & & 2 & $5(9.4)$ & $3(20.0)$ & $2(15.4)$ & & \\
\hline & & & & 3 & $48(90.6)$ & $12(80.0)$ & $11(84.6)$ & 12 (100) & $13(100)$ \\
\hline & \multirow{4}{*}{\multicolumn{2}{|c|}{$\ddot{\ddot{\varphi}}$}} & & 0 & $19(35.8)$ & $6(40.0)$ & $7(53.8)$ & $1(8.3)$ & $5(38.5)$ \\
\hline & & & & 1 & $23(43.4)$ & $9(60.0)$ & $5(38.5)$ & $2(16.7)$ & $7(53.8)$ \\
\hline & & & & 2 & 7 (13.2) & & & $7(58.3)$ & \\
\hline & & & & 3 & $4(7.5)$ & & $1(7.7)$ & $2(16.7)$ & $1(7.7)$ \\
\hline & \multirow{4}{*}{ 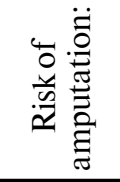 } & - high & & & $23(43.4)$ & $6(40.0)$ & $2(15.4)$ & $9(75.0)$ & $6(46.2)$ \\
\hline & & - medium & & & $11(20.8)$ & $3(20.0)$ & $4(30.8)$ & $2(16.7)$ & $2(15.4)$ \\
\hline & & - low & & & $19(35.8)$ & $6(40.0)$ & $7(53.8)$ & $1(8.3)$ & $5(35.5)$ \\
\hline & & - very low & & & - & - & - & - & - \\
\hline & \multirow{4}{*}{ 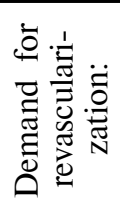 } & - high & & & $34(64.2)$ & $9(60.0)$ & $6(46.2)$ & $11(91.7)$ & $8(61.5)$ \\
\hline & & - medium & & & $14(26.4)$ & $3(20.0)$ & $5(38.5)$ & $1(8.3)$ & $5(38.5)$ \\
\hline & & - low & & & $5(9.4)$ & $3(20.0)$ & $2(15.4)$ & - & - \\
\hline & & - very low & & & - & - & - & - & - \\
\hline
\end{tabular}

Types of lesions of the aortoiliac and femoropopliteal segments

Table 2 in patients of group $I(n=15)$, number of patients $(\%)$

\begin{tabular}{lccccc}
\hline Type of lesions of the aortoiliac segment by TASC & \multicolumn{5}{c}{ Type of lesions of the femoropopliteal segment by TASC } \\
& A & B & C & D & Total \\
\hline A & $2(13.3)$ & $1(6.7)$ & - & $5(33.3)$ & $8(53.3)$ \\
B & $1(6.7)$ & - & - & $1(6.7)$ & $2(13.3)$ \\
C & - & $1(6.7)$ & - & - & $1(6.7)$ \\
D & - & - & - & $4(26.7)$ & $4(26.7)$ \\
Total & $3(20.0)$ & $2(13.3)$ & $0(0)$ & $10(66.7)$ & $15(100)$ \\
\hline
\end{tabular}

endovascular interventions were performed exclusively on the infrapopliteal arterial segment. In 1 patient $(7.7 \%)$, the lesion of this segment was of type A, 1 more was of type B, 2 (15.4\%) had type C, and $9(69.2 \%)$ had type D. In three of these patients
(23.1\%), femoropopliteal segment was affected (type D), but at the time of endovascular intervention they had adequately functioning femoropopliteal shunts with a distinct pulsation on the popliteal artery. 9 of 13 patients $(69.2 \%)$ had angioplasty of one tibia (the 

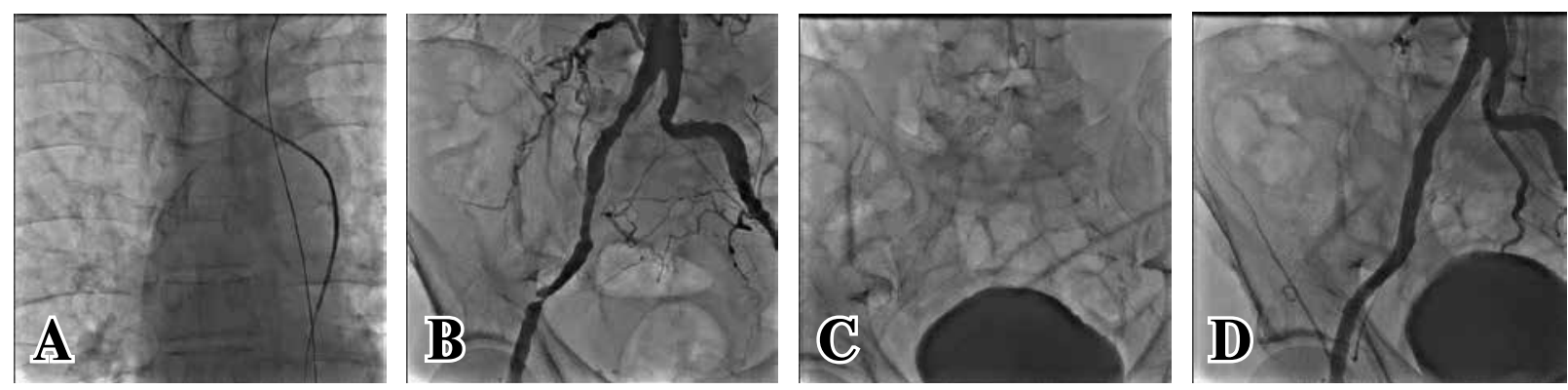

Fig. Stages of implantation of a self-expanding stent to the common and external iliac artery: A - conductors and angiographic catheter in the descending aorta; B - visualization of the affected right common and external iliac arteries;

C - stent after implantation into the common and external iliac artery; D - angiographic control after stenting.

posterior tibial artery only in 1 case and the anterior one - in 8 cases), and 3 of the remaining $(23.1 \%)-$ of two arteries (anterior and posterior tibial arteries). Angioplasty of the peroneal artery was not performed.

For all interventions in this group of patients, transfemoral access through the common femoral artery was used: 9 patients $(69.2 \%)$ had ipsilateral antegrade, and 4 (30.8\%) had a contralateral retrograde. In 3 cases (21.4\%), tibial revascularization was performed through a functioning femoropopliteal shunt. To avoid the shunt puncture, contralateral access was used. After the puncture, the conductor with the help of an angiographic catheter was guided through an abdominal aorta bifurcation to the ipsilateral side with a $90 \mathrm{~cm}$ introducer installation. In stenotic tibial vessels, a single balloon angioplasty tactic was used with a long catheter all along. For the detection of total tibial occlusions, coronary technique of passage with a two-stage balloon plastic, the same as for group IIB, was used.

After the intervention, patients of all groups were treated with antiplatelet and lipid-lowering therapy, as well as correction of all detected risk factors and treatment of lesions of arteries of other basins (coronary, extra- and intracranial, renal) according to the recommendations of the above international consensus documents [2, 3, 4].

34 of 53 patients $(64.2 \%)$ in the lower limbs had necrotic and purulent-necrotic complications (Table 4), their treatment tactics was identical in all groups of patients and met the international standards mentioned above.

In 8 of 34 patients (23.5\%), purulent necrotic complications did not require surgical intervention under anesthesia and were conservative (according to the phases of the wound process): trophic ulcers - in 7 patients and dry necrosis of the toe skin - in 1. In the remaining 26 patients $(76.5 \%)$, the sanation of these foci required surgical interventions under anesthesia. If the focus according to WifI classification by fI criterion was identified as "fI3", or if there was a possibility of a marked progression of the process prior to the planned endovascular intervention, the focus was sanitized immediately, before the endovascular operation. This tactic was used in 7 out of $26(27.0 \%)$ patients. In all other

Table 3

Types of lesions of the femoropopliteal and infrapopliteal segments and characteristics of endovascular interventions performed in patients with IIA and IIB groups, number of patients (\%)

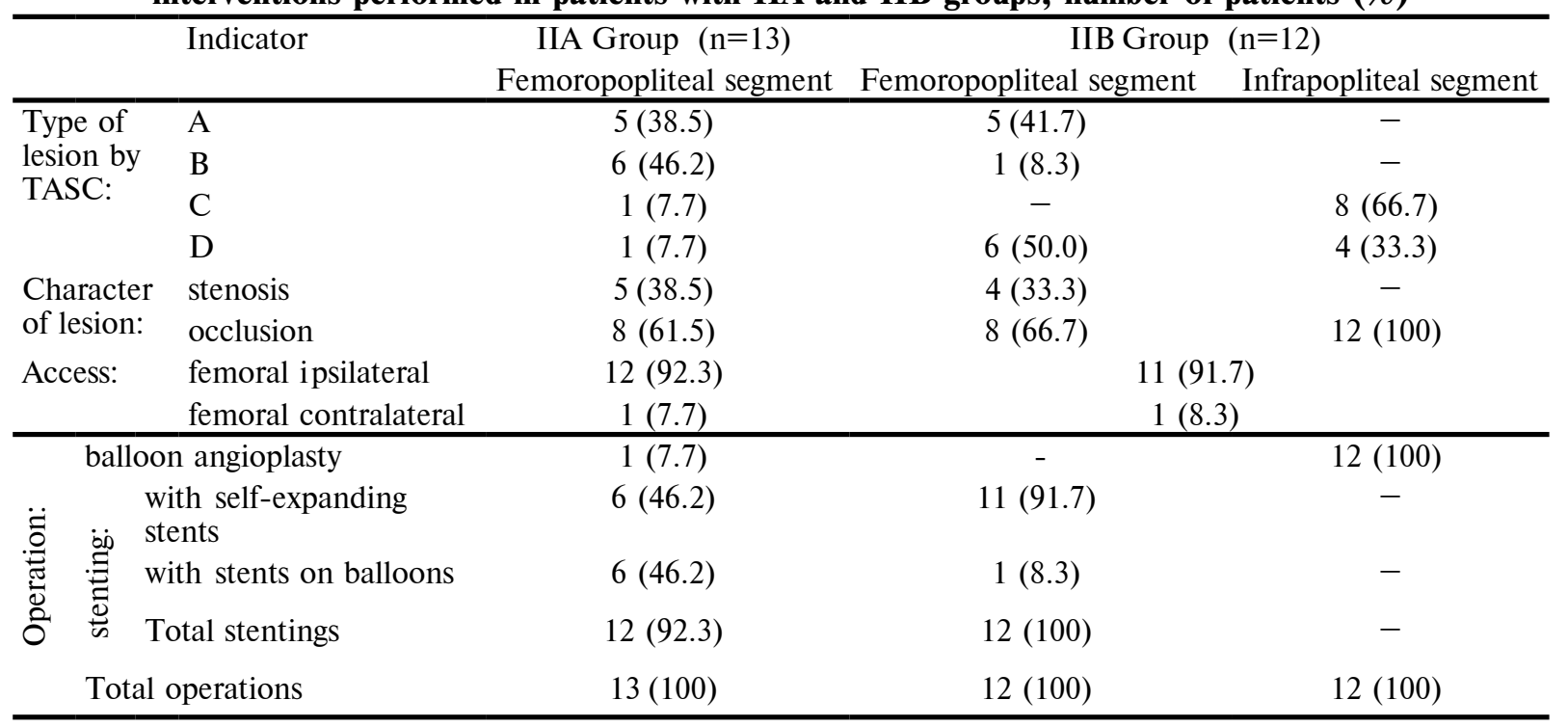


Types of purulent necrotic processes in the feet of patients of different groups, number $(\%)$

\begin{tabular}{lccccc}
\hline Purulent necrotic complications & \multicolumn{3}{c}{ Groups of patients } \\
& $\begin{array}{c}\text { I Group } \\
(\mathrm{n}=15)\end{array}$ & $\begin{array}{c}\text { IIA Group } \\
(\mathrm{n}=13)\end{array}$ & $\begin{array}{c}\text { IIB Group } \\
(\mathrm{n}=12)\end{array}$ & $\begin{array}{c}\text { III Group } \\
(\mathrm{n}=13)\end{array}$ & $\begin{array}{c}\text { All patients } \\
(\mathrm{n}=53)\end{array}$ \\
\hline Trophic ulcers & $3(20.0)$ & $4(30.8)$ & $3(25.0)$ & $2(15.4)$ & $12(22.6)$ \\
Dry skin necrosis & - & $1(7.7)$ & $1(8.3)$ & - & $2(3.8)$ \\
Phlegmon of the foot & - & - & - & $1(7.7)$ & $1(1.9)$ \\
Dry gangrene of toe/s & $5(33.3)$ & $1(7.7)$ & $1(8.3)$ & $1(7.7)$ & $8(15.1)$ \\
Wet gangrene of toe/s & $1(6.7)$ & - & $4(33.3)$ & $3(23,1)$ & $8(15.1)$ \\
Dry gangrene of the distal part of the foot & - & - & - & $1(7.7)$ & $1(1.9)$ \\
Wet gangrene of the distal part of the foot & - & - & $2(16.7)$ & - & $2(3.8)$ \\
Total & $9(60.0)$ & $6(46.1)$ & $11(91.7)$ & $8(61.5)$ & $34(64.2)$ \\
\hline
\end{tabular}

cases, in order to avoid the progression of necrosis, the focus sanation was carried out during (1 patient $-3.9 \%)$ or after the endovascular procedure (18 patients $-69.2 \%)$. In 14 of 18 cases $(77.8 \%)$, the intervention on a purulent necrotic lesion was performed from 1 to 7 days after the endovascular procedure, and in the remaining 4 patients $(22.2 \%)$ later (after a clear demarcation of viable and necrotic tissues). The spectrum of operations: necrectomy with or without abscess disclosure -7 of 26 cases $(27.0 \%)$, toe or toes amputation - 16 cases $(61.5 \%)$ and transverse amputation of the foot -3 cases $(12.5 \%)$. In 5 cases $(19.2 \%)$, from 5 to 74 days after the endovascular procedure, autodermoplasty of the granulating wounds was performed after the primary intervention on the purulent necrotic focus by a free, split perforated skin flap.

The results of patients' treatment were assessed: at the time of finishing the operation; at the time of discharge from the hospital; 1 year after the operation (during the year, patients were examined after 3, 6, 9 and 12 months).

At the end of the operation, the technical success of the endovascular procedure was evaluated. Intervention was considered technically successful if, in control post-procedure angiography, the stenosis or occlusion of the arteries that caused the intervention were eliminated with the renewal of the main blood flow in this section.

At the time of discharge from the hospital and one year after the endovascular procedure, patients were examined and ultrasonography of the arteries of the lower limbs was performed. The presence of complaints of intermittent claudication or rest pains was studied as well as the presence of necrotic foci on the feet and legs, patency and the absence of stenosis at the site of stenting or angioplasty. We also studied the frequency of large amputations of the lower limbs (above the ankles) and lethal outcomes.

\section{Statistics}

Statistical processing of data was carried out using the software "Microsoft Excel 2016 MSO" (Microsoft, USA) and "R" (R Development Core Team, Austria).

Qualitative indicators were presented in absolute $(\mathrm{n})$ and relative $(\%)$ frequencies. When analyzing the quantitative data (the age of patients), the character of distribution of the indicator values was determined using the Shapiro-Wilk W test. The age distribution of the patients turned out to be normal (Gaussian), and therefore parametric statistical indicators were used for its characterization and the results were presented in the form "M( $\sigma)$ " ( where $\mathrm{M}$ is the mean value and $\sigma-$ the standard deviation).

Statistical processing of data was carried out using the software "Microsoft Excel 2016 MSO" (Microsoft, USA) and "R" (R Development Core Team, Austria).

Qualitative indicators were presented in absolute $(n)$ and relative $(\%)$ frequencies. When analyzing the quantitative data (the age of patients), the character of distribution of the indicator values was determined using the Shapiro-Wilk W test. The age distribution of the patients turned out to be normal (Gaussian), and therefore parametric statistical indicators were used for its characterization and the results were presented in the form "M( $\sigma)$ " ( where $M$ is the mean value and $\sigma-$ the standard deviation).

\section{Results}

In Group I, the technical success of endovascular intervention in the aortoiliac arterial segment was $100 \%$, considering one patient who underwent a simultaneous open reconstruction of the femoropopliteal segment. In this and another 3 patients (26.7\%) the primary intervention was enough to eliminate their complaints: intermittent claudication - in 1 patient, rest pain in the foot - also in one and rest pain in the place of the necrotic focus - in 2. Among the latter 2 patients, in one trophic ulcer healed in 3 months of follow-up, 
while in the second patient, after the amputation of the toe, healing occurred by primary tension. The remaining 11 patients $(73.3 \%)$ did not significantly improve symptomatology due to the remaining occlusive process in the femoropopliteal segment. As mentioned above, they underwent a second stage of reconstruction (shunting or endovascular surgery on the femoropopliteal segment). This allowed eliminating intermittent claudication in 2 patients, rest pain in the foot - also in 2 and pain in the place of necrotic process - in the remaining 7. Among the latter 7 operated patients, trophic ulcers healed after local conservative treatment in 2 patients, while the remaining 5 patients underwent amputation of the toe or toes with healing in 3 patients by primary tension, and in 2 patients after the subsequent autodermoplasty. Within 1 year of observation, stent thrombosis was not observed in this group of patients. Starting with the examination after 3 months, unhealed or new necrotic processes on the lower limbs were not observed. One year after the endovascular operation, all the patients retained their lower limbs, all patients were alive, and no patient had lower limb ischemia above the grade IIA by Fontaine.

In the A group of patients the technical success was also $100 \%$. In 2 patients with intermittent claudication and 5 with rest pain without necrotic lesions, these symptoms were eliminated. Among 6 patients with necrotic complications in 5, they healed conservatively before the 3-month observation (in one of them after additional necrectomy), and 1 patient underwent the amputation of the finger with primary-tension healing. As in Group I, 1 year after the endovascular operation, all the patients retained their lower limbs, all patients were alive, no patient had lower limb ischemia above grade IIA by Fontaine.

In the B group, only in one patient the complete revascularization failed. She had wet gangrene of the distal part of the foot against the background of multiple critical stenosis of the femoral and all 3 tibial arteries, as well as severe concomitant cardiac pathology and multiple organ failure. She underwent transmetatarsal foot amputation, stenting of the femoral artery and unsuccessful attempts to perform balloon plastic of the tibial arteries. One-story revascularization did not give clinical improvement. Later, she underwent the amputation of the lower limb at the level of the upper third of the thigh according to vital indications. After 6 days, the patient died from the progression of multiple organ failure.

Within 1 year of the study, in this group of patients, stent thrombosis occurred in $2(15.4 \%)$ patients with the technical success of the procedure. One of them showed pronounced calcification of the femoral artery, occlusion of the popliteal artery, tibioperoneal trunk and proximal segments of all 3 tibial arteries. After the stenting of the popliteal artery and the balloon plastic of the tibial arteries, an early thrombosis of the stent occurred $(<24 \mathrm{~h})$. It was caused by the use of the device to close the puncture hole, which anchored its anchor to the calcified plaque on the opposite wall of the common femoral artery, covering most of the lumen of the vessel and causing stent thrombosis. As a consequence, it was not possible to restore the blood supply endovascularly. Urgent total femoral-posterior tibial autovenous shunting was performed. After 12 days, the patient had acute thrombosis of the shunt, reshunting was performed, replacing the suprapopliteal part of the shunt with the alloprosthesis. After 3 months, there was a repeated thrombosis of the shunt. The conditions for the re-reconstruction were considered unsatisfactory. The limb was amputated at the level of the upper third of the thigh.

In the second patient, after stenting of the femoral artery (critical stenosis), balloon plastic surgery of the tibial arteries (proximal occlusion) and amputation of two toes with wound healing by primary tension, thrombosis of the stent took place 7 months after the intervention. The patient underwent thrombectomy and a careful analysis revealed that the cause of thrombosis was the dissection of the popliteal artery distally to the stent. After that, the second stent in the popliteal artery was implanted in more distal location than the previous one (with partial overlap) with complete restoration of the blood flow.

Among the remaining 9 patients of the IIB group the results were as follows: 1) disappearance of rest pain in the absence of necrotic complications - 1 patient; 2) healing of the trophic ulcer 3 patients (one patient - under the influence of conservative treatment, the other - after surgical necrectomy, in the third - after additional autodermoplasty); 3 ) wound healing by primary tension after toes amputation (3 patients) or transmetatarsal foot amputation (1 patient); 4) wound healing after toes amputation and subsequent autodermoplasty 1 patient. Three months after revascularization, the necrotic processes on the limbs in these patients were not identified.

As a result, $91.7 \%$ of patients managed to achieve technical success in this group, to save lower limbs on the background of the functioning of the reconstruction zones and the absence of chronic ischemia above the IIA degree during a year - in 10 of 12 patients (83.3\%). 11 of 12 patients (91.7\%) survived.

Technical success in the last III group was $84.6 \%$ (11 of 13 patients). Two patients failed to restore the main blood supply. One of these patients was treated with a sluggish wound after amputation of the first 
toe of the left foot due to his wet gangrene without a tendency to heal. The patient underwent arteriography and the occlusion of both tibial arteries in the distal segments with pronounced calcification of their walls was found (mediacalcinosis of Menkeberg). An attempt was made to restore blood flow. However, it was not possible to pass through the calcified closed sections of the artery using microcatheters and conductors of different sizes, rigidity and patency. In spite of this, the limb was saved, although even one year after the endovascular procedure, complete wound healing was not achieved

The next patient was hospitalized with thrombosis of the femoropopliteal shunt. Surgically, he underwent thrombectomy from the shunt with restoration of blood flow and postoperative arteriography. The cause of thrombosis of the shunt is the failure of the peripheral arterial channel (extended occlusions of the posterior and anterior tibial arteries). From the contralateral access through the functioning femoropopliteal shunt, the balloon plastic of these arteries with thromboaspiration was performed. Despite multiple attempts, the angiographic result was unsatisfactory, by the time of the end of the procedure; there was no distal blood flow. However, due to the functioning of the shunt, acute arterial insufficiency in the patient was eliminated. During the year, the patient had another 2 shunt thrombosis (after 6 and 8 months), but both times the thrombectomy from the shunt was successful. There were no symptoms of ischemia a year after the endovascular procedure.

Among 11 patients in whom the blood flow was restored successfully, in one 3 months after, there was a reocclusion of the anterior tibial artery with the phenomena of critical ischemia, which was eliminated by repeated ballooning. After 4 months, repeated reocclusion was eliminated by balloon plastic and stenting of the middle third of the anterior tibial artery with two coronary stents (bare-metal stent). Three months after the last operation, the patient was repeatedly hospitalized with the phenomena of critical ischemia. On examina- tion, the appearance of a new critical stenosis of the anterior tibial artery and restenosis in the stent were discovered. They were eliminated by the next balloon plasty of the anterior tibial artery but with a larger catheter $3.0(150 \mathrm{~mm})$ and stenting of its orifice with a single coronary stent (bare-metal stent). After 1 year of observation, the signs of ischemia were not detected.

Among the remaining 10 patients of the III groups of results were as follows: 1 ) the disappearance of rest pain in the absence of necrotic complications - 4 patients; 2) healing of the trophic ulcer -2 patients (one patient - as a result of conservative treatment, the other - after surgical necrectomy); 3 ) wound healing after opening the phlegmon of the foot -1 patient; 4 ) wound healing by primary tension after toe amputation - 4 cases; 5) wound healing after transmetatarsal foot amputation and subsequent autodermoplasty -1 patient. Three months after revascularization, the necrotic processes on the limbs in these patients were not identified.

As a result, throughout a year, one managed to achieve the reconstruction zones functioning and absence of chronic ischemia above IIA degree in 11 out of 13 patients $(91.7 \%)$ of the III group, to save the lower limbs - in $100 \%$ of patients.

As a result, out of 53 patients in 4 groups, technical success was achieved in 50 patients $(94.3 \%)$ (Table 5), the primary patency of the revascularized segments of the arteries during the year was recorded in $88.7 \%$ of patients, their secondary passability for this time - in $92.5 \%$, the preservation of the lower limbs was achieved in $96.2 \%$ of cases, and the absence of lethal outcomes - in 98.1\% (Table 6).

Within a year after the operation, there were no indications for repeated procedures in connection with restenosis of the reconstruction zone. The only serious complication associated with the endovascular procedure was the above-analyzed stent thrombosis in the superficial femoral artery, due to the use of the device to close the puncture hole. Death, myocardial infarction, strokes, acute kidney failure, life-threatening bleeding and hema-

Table 5

\section{Results of treatment in patients of different groups}

\section{1 year after endovascular intervention, (abs.number $/ \%$ )}

\begin{tabular}{|c|c|c|c|c|c|}
\hline \multirow{2}{*}{ Indicator } & \multicolumn{5}{|c|}{ Groups of patients } \\
\hline & $\begin{array}{l}\text { I Group } \\
(\mathrm{n}=15)\end{array}$ & $\begin{array}{l}\text { IIA Group } \\
(\mathrm{n}=13)\end{array}$ & $\begin{array}{c}\text { IIB Group } \\
(\mathrm{n}=12)\end{array}$ & $\begin{array}{l}\text { III Group } \\
(\mathrm{n}=13)\end{array}$ & $\begin{array}{c}\text { All patients } \\
(\mathrm{n}=53)\end{array}$ \\
\hline Technical success of the endovascular 0 & $15 / 100 \%$ & $13 / 100 \%$ & $11 / 91.7 \%$ & $11 / 84.6 \%$ & $50 / 94.3 \%$ \\
\hline $\begin{array}{l}\text { Thrombosis or reocclusion of the angioplasty or stent } \\
\text { zone with a repeated successful endovascular operation }\end{array}$ & $0 / 0 \%$ & $0 / 0 \%$ & $1 / 8.3 \%$ & $1 / 7.7 \%$ & $2 / 3.8 \%$ \\
\hline $\begin{array}{l}\text { Thrombosis or reocclusion of the angioplasty or } \\
\text { stent zone without repeated endovascular surgery }\end{array}$ & $0 / 0 \%$ & $0 / 0 \%$ & $1 / 8.3 \%$ & $0 / 0 \%$ & $1 / 1.9 \%$ \\
\hline Primary passability of the stent or angioplasty zone & $15 / 100 \%$ & $13 / 100 \%$ & $9 / 75 \%$ & $10 / 76.9 \%$ & $47 / 88.7 \%$ \\
\hline $\begin{array}{l}\text { Secondary passability of the stent or angioplasty } \\
\text { zone }\end{array}$ & - & - & $10 / 83.3 \%$ & $11 / 84.6 \%$ & $49 / 92.5 \%$ \\
\hline
\end{tabular}




\begin{tabular}{|c|c|c|c|c|c|}
\hline \multicolumn{6}{|c|}{$\begin{array}{l}\text { Clinical results of treatment of patients of different groups } \\
1 \text { year after endovascular intervention (abs. number/\%) }\end{array}$} \\
\hline \multirow[t]{2}{*}{ Indicator } & \multicolumn{5}{|c|}{ Groups of patients } \\
\hline & $\begin{array}{l}\text { Group } \\
(n=15)\end{array}$ & $\begin{array}{l}\text { IIA Group } \\
(\mathrm{n}=13)\end{array}$ & $\begin{array}{l}\text { IIB Group } \\
(\mathrm{n}=12)\end{array}$ & $\begin{array}{c}\text { III Group } \\
(\mathrm{n}=13)\end{array}$ & $\begin{array}{l}\text { All patients } \\
(\mathrm{n}=53)\end{array}$ \\
\hline Absence of chronic limb ischemia above IIA degree & $15 / 100 \%$ & $13 / 100 \%$ & $10 / 83.3 \%$ & $12 / 92.3 \%$ & $50 / 94.3 \%$ \\
\hline Chronic limb ischemia IIB-IV degree & $0 / 0 \%$ & $0 / 0 \%$ & $0 / 0 \%$ & $1 / 7.7 \%$ & $1 / 1.9 \%$ \\
\hline Large amputation of the limb (above the ankles) & $0 / 0 \%$ & $0 / 0 \%$ & $2 / 16 \%$ & $0 / 0 \%$ & $2 / 3.8 \%$ \\
\hline Preservation of the lower limb & $15 / 100 \%$ & $13 / 100 \%$ & $10 / 83.3 \%$ & $13 / 100 \%$ & $51 / 96.2 \%$ \\
\hline Lethality & $0 / 0 \%$ & $0 / 0 \%$ & $1 / 8.3 \%$ & $0 / 0 \%$ & $1 / 1.9 \%$ \\
\hline Survival rate & $15 / 100 \%$ & $13 / 100 \%$ & $11 / 91.7 \%$ & $13 / 100 \%$ & $52 / 98.1 \%$ \\
\hline
\end{tabular}

tomas were not observed.

\section{Discussions}

Endovascular surgery has changed so dramatically over the past 5 years that it is difficult for the leading consensus documents to keep pace with these changes today [8]. Therefore, any detailed publication of new results in this area is doubly relevant. Our study concerned endovascular operations on all 3 arterial segments of the lower limb, and therefore permits us to draw a number of interesting conclusions.

According to the above-mentioned document, which regulated the choice of our operating tactics, indications for the primary use of endovascular procedures for revascularization of the aortoiliac segment are: 1) short occlusive-stenotic lesions $(<5$ $\mathrm{cm})$; 2) any other lesions in the patient's severe general state; 3) planning of a hybrid procedure in case the demand for revascularization and aortoiliac, and femoropopliteal segment. The third indication has a rather low degree of evidence $-\mathrm{aC}$. Since in our study the majority of patients ( 9 out of 15 ) were performed the procedure for this indication, the results obtained by us again confirm its validity: $100 \%$ of technical success, $100 \%$ of the initial passability during the year and $100 \%$ of the absence of chronic limb ischemia above IIA degree. These results are comparable with the generalized literature data on the endovascular procedures on the aortoiliac segment: $82-98 \%$ of technical success [9]. Thus, the results of treatment for patients who underwent endovascular revascularization in hybrid operations on the aortoiliac and femoropopliteal segments are comparable to the results of endovascular elimination of isolated lesions of the aortoiliac segment. All this is an additional argument for the justification of such tactics.

In endovascular interventions on the femoropopliteal segment, stenoses or occlusions $<25 \mathrm{~cm}$ in length, which approximately correspond to A-C types of TASC lesions, were the main indication for the primary use of endovascular procedures, except for the general condition of the patient in- compatible with surgery. A recent systematic review demonstrated the primary passability of this segment during the year following endoscopy in $58.3 \%$ of patients [10], although in some single-center studies it reached $74.7 \%$ for type D lesions [11] for which endovascular interventions are not a strategy of choice. Our study showed a clear trend of the dependence of the results on the presence or absence of concomitant infrapopliteal lesions. In the IIA group, the primary passability of the reconstruction zone for 1 year was $100 \%$, which is significantly higher than in the mentioned above systematic review. In contrast, in the IIB group it was only $75 \%$, which is comparable to the above studies. In our opinion, it was this (IIB) group that was the most difficult in terms of achieving positive results.

In infrapopliteal occlusive-stenotic lesions, according to the above-mentioned document, which governed the choice of our operational tactics, a large saphenous vein shunting has the highest class of recommendations and the level of evidence (IA). And thus, the only indication for the endovascular treatment of this segment is the patient's severe general condition, incompatible with large revascularizing open operations, which is competent to treat the lesions of any arterial segment. Nevertheless, some experts consider the endovascular strategy for infrapopliteal lesions to be the current standard, which provides technical success in $77-100 \%$ of cases [12] and preservation of the limb for 3 years in $82.4 \%$ of patients [13]. Among our patients of the third group, the indications to the endovascular operation were not only the patient's severe condition, but also the variant of the infrapopliteal segment lesion, in which an open operation is impossible or its success is doubtful: total occlusion of all the major arteries of the lower leg and foot or total circular calcification of the post-occlusal segments of the arteries of the shin and feet with a low probability of imposing a distal anastomosis. Such patients accounted for an absolute majority of the III group ( 9 of 13 cases). The results of their treatment: technical success in $84.6 \%$ of cases, primary passability of the angioplasty zone during the 
year - in $76.9 \%$ and limb preservation in $100 \%$, give grounds to recommend continuing study of endovascular angioplasty as the main method of treatment of such patients.

It should be separately said about the endovascular treatment of patients with lesions of type $\mathrm{D}$ of the arterial segment according to the TASC classification. Such patients with a positive result of treatment were in all the groups that we identified. We believe that the type D lesions of any segment of the arteries of the lower limbs is quite heterogeneous and the selection of those of its variants, for which endovascular treatment is optimal, may be a promising direction for future studies.

\section{Conclusions}

1. The weighted application of endovascular and combined revascularization methods in patients with occlusive-stenotic lesions of different segments of the arteries of the lower limbs made it possible to achieve technical success of intervention in $94.3 \%$ of patients, the primary patency of revascularized segments of arteries during the year - in $88.7 \%$, their secondary passability during this time - in $92.5 \%$, the preservation of the lower limbs - in $96.2 \%$ and the absence of lethal outcomes - in $98.1 \%$.

2. The technical impossibility or the low probability of the success of an open surgical operation on the infrapopliteal arterial segment can be considered as an indication to the endovascular procedure. Identically, the simultaneous lesion of the aortoiliac and femoropopliteal arterial segments can serve as an indication for hybrid procedures in which the top floor needs to be revascularized endovascularly.

3 . The use of devices to close the puncture hole should be weighed in cases of atherosclerotic lesion of the common femoral artery and should not be used with the available calcination of this vessel.

\section{Funding}

The work was carried out in accordance with the plan of scientific works of Ivano-Frankivsk National Medical University. The authors did not receive financial support from the companies, manufacturing pharmaceuticals and medical products.

\section{Conflict of interest}

The authors declare that they have no conflict of interest.

\section{Ethics Committee approval}

The study was approved by a commission of bioethics of Ivano-Frankivsk National Medical University. (Protocol № 78/16, 02.03.16).

\section{ЛИТЕРАТУРА}

1. Mehaffey JH, Hawkins R, Fashandi A, Tracci MC, Cherry K, Kron I, Upchurch G, Robinson WP. Lower extremity bypass is associated with lower short-term major adverse limb events and equivalent major adverse cardiac events compared with endovascular intervention in a national cohort with critical limb ischemia. J Vascr Surg. 2017 Jan;65(Is 1):e4-e5. doi: http://dx.doi.org/10.1016/j. jvs.2016.10.018

2. Norgren L, Hiatt WR, Dormandy JA, Nehler MR, Harris KA, Fowkes FG; TASC II Working Group, Bell K, Caporusso J, Durand-Zaleski I, Komori K, Lammer J, Liapis C, Novo S, Razavi M, Robbs J, Schaper N, Shigematsu H, Sapoval M, White C, White J, Clement D, Creager M, Jaff M, Mohler E $3^{\text {rd }}$, Rutherford RB, Sheehan P, Sillesen H, Rosenfield K. Inter-society consensus for the management of peripheral arterial Disease (TASC II). Eur J Vasc Endovasc Surg. 2007;33 (Suppl 1):S1-75. doi: 10.1016/j.ejvs.2006.09.024

3. Tendera M, Aboyans V, Bartelink ML, Baumgartner I, Clément D, Collet JP, Cremonesi A, De Carlo M, Erbel R, Fowkes FG, Heras M, Kownator S, Minar E, Ostergren J, Poldermans D, Riambau V, Roffi M, Röther J, Sievert H, van Sambeek M, Zeller T. ESC Guidelines on the diagnosis and treatment of peripheral artery diseases: Document covering atherosclerotic disease of extracranial carotid and vertebral, mesenteric, renal, upper and lower extremity arteries: the Task force on the diagnosis and treatment of peripheral artery diseases of the european society of cardiology (ESC). Eur Heart $J$. 2011 Nov;32(22):2851-906. doi: 10.1093/eurheartj/ehr211 4. Aboyans V, Ricco JB, Bartelink MLEL, Björck M, Brodmann M, Cohnert T, Collet JP, Czerny M, De Carlo M, Debus S, Espinola-Klein C, Kahan T, Kownator S, Mazzolai L, Naylor AR, Roffi M, Röther J, Sprynger M, Tendera M, Tepe G, Venermo M, Vlachopoulos C, Desormais I. Editor's Choice - 2017 ESC Guidelines on the Diagnosis and Treatment of Peripheral Arterial Diseases, in collaboration with the European Society for Vascular Surgery (ESVS). Eur J Vasc Endovasc Surg. 2018;55(3):305-68. doi:10.1016/j.ejvs.2017.07.018

5. Stoner MC, Calligaro KD, Chaer RA, Dietzek AM, Farber A, Guzman RJ, Hamdan AD, Landry GJ, Yamagu DJ. Reporting standards of the Society for Vascular Surgery for endovascular treatment of chronic lower extremity peripheral artery disease. J Vasc Surg. 2016 Jul;64(1):e1-e21. doi: 10.1016/j.jvs.2016.03.420

6. Mills JL Sr, Conte MS, Armstrong DG, Pomposelli FB, Schanzer A, Sidawy AN, Andros G. The Society for Vascular Surgery Lower Extremity Threatened Limb Classification System: risk stratification based on wound, ischemia, and foot infection (WIfI). J Vasc Surg. 2014 Jan;59(1):220-34.e1-2. doi: 10.1016/j.jvs.2013.08.003

7. TASC Steering Committee, Jaff MR, White CJ, Hiatt WR, Fowkes GR, Dormandy J, Razavi M, Reekers J, Norgren L. An update on methods for revascularization and expansion of the TASC lesion classification to include below-the-knee arteries: a supplement to the inter-society consensus for the management of peripheral arterial disease (TASC II). Ann Vasc Dis. 2015;8(4):343-357. doi: 10.1177/1358863X15597877

8. Olin JW, White CJ, Armstrong EJ, Kadian-Dodov D, Hiatt WR. Peripheral artery disease: evolving role of exercise, medical therapy, and endovascular options. $J \mathrm{Am}$ Coll Cardiol. 2016 Mar 22;67(11):1338-57. doi: 10.1016/j. jacc.2015.12.049

9. Clair DG, Beach JM. Strategies for managing aor- 
toiliac occlusions: access, treatment and outcomes. Expert Rev Cardiovasc Ther. 2015 May;13(5):551-63. doi: 10.1586/14779072.2015.1036741

10. Antoniou GA, Georgiadis GS, Antoniou SA, Makar RR, Smout JD, Torella F. Bypass surgery for chronic lower limb ischaemia. Cochrane Database Syst Rev. 2017 Apr 3;4:CD002000. doi: 10.1002/14651858.CD002000. pub3

11. Голощапов-Аксенов РС, Шугушев 3X, Матвеев ДВ, Максимкин ДА, Лакунин КЮ. Оценка эффективности рентгенэндоваскулярного лечения больных облитерирующим атеросклерозом артерий нижних конечностей с протяженными окклюзиями поверхностной бедренной артерии. Вестн РУДН. Сер Медииина. 2017;21(2):234-45. doi: 10.22363/2313-02452017-21-2-234-245

12. Gray BH, Diaz-Sandoval LJ, Dieter RS, Jaff MR, White CJ. SCAI expert consensus statement for infrapopliteal arterial intervention appropriate use. Catheter Cardiovasc Interv. 2014 Oct 1;84(4):539-45. doi: 10.1002/ ccd. 25395

13. TASC Steering Committee, Jaff MR, White CJ, Hiatt WR, Fowkes GR, Dormandy J, Razavi M, Reekers J, Norgren L. An update on methods for revascularization and expansion of the TASC lesion classification to include below-the-knee arteries: a supplement to the inter-society consensus for the management of peripheral arterial disease (TASC II). Vasc Med. 2015 Oct;20(5):465-78. doi: $10.1177 / 1358863 \mathrm{X} 15597877$

\section{REFERENCES}

1. Mehaffey JH, Hawkins R, Fashandi A, Tracci MC, Cherry K, Kron I, Upchurch G, Robinson WP. Lower extremity bypass is associated with lower short-term major adverse limb events and equivalent major adverse cardiac events compared with endovascular intervention in a national cohort with critical limb ischemia. $J$ Vascr Surg. 2017 Jan;65(Is 1):e4-e5. doi: http://dx.doi.org/10.1016/j. jvs.2016.10.018

2. Norgren L, Hiatt WR, Dormandy JA, Nehler MR, Harris KA, Fowkes FG; TASC II Working Group, Bell K, Caporusso J, Durand-Zaleski I, Komori K, Lammer J, Liapis C, Novo S, Razavi M, Robbs J, Schaper N, Shigematsu H, Sapoval M, White C, White J, Clement D, Creager M, Jaff M, Mohler E 3rd, Rutherford RB, Sheehan P, Sillesen H, Rosenfield K. Inter-society consensus for the management of peripheral arterial disease (TASC II). Eur J Vasc Endovasc Surg. 2007;33 (Suppl 1):S1-75. doi: 10.1016/j.ejvs.2006.09.024 3. Tendera M, Aboyans V, Bartelink ML, Baumgartner I, Clément D, Collet JP, Cremonesi A, De Carlo M, Erbel R, Fowkes FG, Heras M, Kownator S, Minar E, Ostergren J, Poldermans D, Riambau V, Roffi M, Röther J, Sievert H, van Sambeek M, Zeller T. ESC Guidelines on the diagnosis and treatment of peripheral artery diseases: Document covering atherosclerotic disease of extracranial carotid and vertebral, mesenteric, renal, upper and lower extremity arteries: the task force on the diagnosis and treatment of peripheral artery diseases of the european society of cardiology (ESC). Eur Heart $J$. 2011 Nov;32(22):2851-906. doi: 10.1093/eurheartj/ehr211 4. Aboyans V, Ricco JB, Bartelink MLEL, Björck M,

\section{Адрес для корреспонденции}

76018, Украина, г. Ивано-Франковск, ул. Галицкая, 2,
Brodmann M, Cohnert T, Collet JP, Czerny M, De Carlo M, Debus S, Espinola-Klein C, Kahan T, Kownator S, Mazzolai L, Naylor AR, Roffi M, Röther J, Sprynger M, Tendera M, Tepe G, Venermo M, Vlachopoulos C, Desormais I. Editor's Choice - 2017 ESC Guidelines on the Diagnosis and Treatment of Peripheral Arterial Diseases, in collaboration with the European Society for Vascular Surgery (ESVS). Eur J Vasc Endovasc Surg. 2018;55(3):305-68. doi:10.1016/j.ejvs.2017.07.018

5. Stoner MC, Calligaro KD, Chaer RA, Dietzek AM, Farber A, Guzman RJ, Hamdan AD, Landry GJ, Yamagu DJ. Reporting standards of the Society for Vascular Surgery for endovascular treatment of chronic lower extremity peripheral artery disease. J Vasc Surg. 2016 Jul;64(1):e1-e21. doi: 10.1016/j.jvs.2016.03.420

6. Mills JL Sr, Conte MS, Armstrong DG, Pomposelli FB, Schanzer A, Sidawy AN, Andros G. The Society for Vascular Surgery Lower Extremity Threatened Limb Classification System: risk stratification based on wound, ischemia, and foot infection (WIfI). J Vasc Surg. 2014 Jan;59(1):220-34.e1-2. doi: 10.1016/j.jvs.2013.08.003 7. TASC Steering Committee, Jaff MR, White CJ, Hiatt WR, Fowkes GR, Dormandy J, Razavi M, Reekers J, Norgren L. An update on methods for revascularization and expansion of the TASC lesion classification to include below-the-knee arteries: a supplement to the inter-society consensus for the management of peripheral arterial disease (TASC II). Ann Vasc Dis. 2015;8(4):343-57. doi: $10.1177 / 1358863 X 15597877$

8. Olin JW, White CJ, Armstrong EJ, Kadian-Dodov D, Hiatt WR. Peripheral artery disease: evolving role of exercise, medical therapy, and endovascular options. $\mathrm{J} \mathrm{Am}$ Coll Cardiol. 2016 Mar 22;67(11):1338-57. doi: 10.1016/j. jacc.2015.12.049

9. Clair DG, Beach JM. Strategies for managing aortoiliac occlusions: access, treatment and outcomes. Expert Rev Cardiovasc Ther. 2015 May;13(5):551-63. doi: 10.1586/14779072.2015.1036741

10. Antoniou GA, Georgiadis GS, Antoniou SA, Makar RR, Smout JD, Torella F. Bypass surgery for chronic lower limb ischaemia. Cochrane Database Syst Rev. 2017 Apr 3;4:CD002000. doi: 10.1002/14651858.CD002000. pub3

11. Goloshchapov-Aksenov RS, Shugushev ZKh, Matveev DV, Maximkin DA, Lakunin KYu. Evaluation of the effectiveness of endovascular treatment of patients with obliterating atherosclerosis of lower limb arteries with long occlusions of the superficial femoral artery. Vestn RUDN. Ser Meditsina.2017;21(2):234-45. doi: 10.22363/2313-0245-2017-21-2-234-245 (in Russ.)

12. Gray BH, Diaz-Sandoval LJ, Dieter RS, Jaff MR, White CJ. SCAI expert consensus statement for infrapopliteal arterial intervention appropriate use. Catheter Cardiovasc Interv. 2014 Oct 1;84(4):539-45. doi: 10.1002/ ccd. 25395

13. TASC Steering Committee, Jaff MR, White CJ, Hiatt WR, Fowkes GR, Dormandy J, Razavi M, Reekers J, Norgren L. An update on methods for revascularization and expansion of the TASC lesion classification to include below-the-knee arteries: a supplement to the inter-society consensus for the management of peripheral arterial disease (TASC II). Vasc Med. 2015 Oct;20(5):465-78. doi: $10.1177 / 1358863 X 15597877$

\section{Address for correspondence}

76018, Ukraine,

Ivano-Frankivsk, Galitskaya Str., 2, 
Ивано-Франковский национальный медицинский университет, кафедра хирургии стоматологического факультета, тел.: +38-097-933-52-94, e-mail: r.sabadosh@gmail.com, Сабадош Ростислав Васильевич

\section{Сведения об авторах}

Совтус Олег Фёдорович, аспирант кафедры хирургии стоматологического факультета, Ивано-Франковский национальный медицинский университет, г. Ивано-Франковск, Украина.

http://orcid.org/0000-0001-9125-7570

Сабадош Ростислав Васильевич, д.м.н., профессор кафедры хирургии стоматологического факультета, Ивано-Франковский национальный медицинский университет, г. Ивано-Франковск, Украина. http://orcid.org/0000-0001-9770-5960

\section{Информация о статье}

Поступила октября 2017 г.

Принята в печать 3 сентября 2018 г. Доступна на сайте 31 октября 2018 г.
Ivano-Frankivsk National Medical University, Surgery Department of the Stomatological Faculty, Tel. +38-097-933-52-94,

e-mail: r.sabadosh@gmail.com,

Rostyslav V. Sabadosh

\section{Information about the authors}

Sovtus Oleg F., Post-Graduate Student of the Surgery Department of the Stomatological Faculty, Ivano-Frankivsk National Medical University, IvanoFrankivsk, Ukraine. http://orcid.org/0000-0001-9125-7570

Sabadosh Rostislav V., MD, Professor of the Surgery Department of the Stomatological Faculty, IvanoFrankivsk National Medical University, IvanoFrankivsk, Ukraine.

http://orcid.org/0000-0001-9770-5960

\section{Article history}

Arrived October 2017

Accepted for publication 3 September 2018 Available online 31 October 2018 